\title{
Treponema brennaborense sp. nov., a novel spirochaete isolated from a dairy cow suffering from digital dermatitis
}

\author{
Kirstin Schrank, ${ }^{1}$ Bong-Kyu Choi, ${ }^{2}$ Siegfried Grund, ${ }^{3}$ Annette Moter, ${ }^{4}$ \\ Klaus Heuner, ${ }^{4}$ Herbert Nattermann ${ }^{1}$ and UIf B. Göbel ${ }^{4}$
}

Author for correspondence: Ulf B. Göbel. Tel: +49302093 4715. Fax: +493020934703. e-mail: ulf.goebel@charite.de

\footnotetext{
1 Institut für Mikrobiologie und Tierseuchen der Freien Universităt Berlin, Luisenstr. 56, D-10117 Berlin, Germany

2 Department of Oral Biology, Yonsei University, College of Dentistry, 134 Shinchon-Dong, 120-752 Seoul, Korea

3 Institut für Mikrobiologie und Tierseuchen der Freien Universităt Berlin, Elektronenmikroskopie, Fabeckstr. 36a, D-14195 Berlin, Germany

4 Institut für Mikrobiologie und Hygiene, Universitătsklinikum Charité, HumboldtUniversität zu Berlin, Dorotheenstr. 96, D-10117 Berlin, Germany
}

\begin{abstract}
A novel Treponema species was isolated from an ulcerative lesion of a cow suffering from digital dermatitis (DD), a disease which causes painful ulcerations along the coronary band. Among other anaerobic bacteria, high numbers of spirochaetes have been regularly found in DD lesions. Here data are presented of a spirochaete isolated from a DD ulcer. By chemotaxonomy, protein analysis and comparative 165 rDNA sequence analysis this isolate was classified as a treponeme that differed from all Treponema species described previously. The only isolate, DD5/3 ${ }^{\top}$, for which the name Treponema brennaborense is proposed, is designated the type strain of the novel species. The strain is a small, highly motile spirochaete that has two periplasmic flagella, one flagellum being attached at each cell pole. Strain DD5/3 ${ }^{\top}$ exhibits $\alpha$-glucosidase and $N$-acetyl- $\beta$-glucosaminidase activity and growth is inhibited by rabbit serum. $T$. brennaborense was phylogenetically most closely related (89.5\% 165 rRNA similarity) to Treponema maltophilum, an oral spirochaete isolated from a periodontitis patient.
\end{abstract}

Keywords: treponemes, digital dermatitis, cattle, 16S rRNA

\section{INTRODUCTION}

Digital dermatitis (DD) is an acute or chronic inflammatory disease of the bovine foot and was first described by Cheli \& Mortellaro (1974). The infection occurs with high incidence and leads to a significant decrease in body weight and milk production, causing significant economic losses worldwide (Blowey \& Sharp, 1988). The painful DD lesions, typically found along the coronary band, are red, ulcerative and have a characteristic foul odour (Blowey \& Sharp, 1988). Due to a loss of keratin, the superficial layers of the epidermis are eroded, leading to epithelial hyperplasia and sometimes to a granulomatous surface similar to a strawberry.

Gram-negative rods and significant numbers of spirochaetes were found by microscopic analyses in touchpreparations of specimens taken from DD lesions

\footnotetext{
Abbreviations: DD, digital dermatitis; FISH, fluorescence in situ hybridization.

The GenBank/EMBL accession number for the 16S rDNA sequence of the novel isolate Treponema brennaborense is $\mathrm{Y} 16568$.
}

(Choi et al., 1997; Done et al., 1993; Döpfer et al., 1997; Read et al., 1992). Porphyromonas levii, Fusobacterium necrophorum, Fusobacterium nucleatum, Prevotella oralis, Prevotella denticola, Prevotella bivia (Nattermann et al., 1996) and as yet unclassified spirochaetes (Walker et al., 1995) were isolated from DD specimens. Recently, we identified by electron microscopy different spirochaetal morphotypes in DD lesions (Grund et al., 1995). The presence of high numbers of spirochaetes suggested a causative role of these bacteria in the aetiopathogenesis of this infection (Collighan \& Woodward, 1997; Döpfer et al., 1997; Read et al., 1992; Walker et al., 1997). However, the aetiology of this mixed bacterial infection is still under discussion.

Previous molecular analyses of DD material revealed five spirochaetal phylotypes all clustering within the genus Treponema (Choi et al., 1997), some of which were closely related to treponemes associated with human periodontitis (Choi et al., 1997; Collighan \& Woodward, 1997; Rijpkema et al., 1997).

Here we describe a novel strain isolated from DD lesions in cattle. Phenotypic and genotypic charac- 
terization indicates that this strain represents a novel treponeme species. In this paper we analysed its protein pattern and morphological and biochemical characteristics.

\section{METHODS}

Reference strains. The following type and reference strains were maintained as described previously (Wyss et al., 1996): Treponema denticola CD-1, Treponema pectinovorum ATCC $33768^{\mathrm{T}}$ ( $\mathrm{T}=$ type strain), Treponema socranskii subsp. buccale ATCC $35534^{\mathrm{T}}$, Treponema socranskii subsp. paredis ATCC $35535^{\mathrm{T}}$, Treponema socranskii subsp. socranskii ATCC $35536^{\mathrm{T}}$, 'Treponema vincentii' LA-1 (= ATCC 35580), Treponema maltophilum ATCC $51939^{\mathrm{T}}$ and 'Treponema phagedenis' biotype Reiter, kindly provided by B. Wilske, Ludwigs-Maximiliaus-Universität München, Germany.

Material, media and culture conditions. A biopsy $(1 \times 2 \times$ $0.5 \mathrm{~cm}$ ) from an infected dairy cow (ear-clip: 1219, Dretzener Landprodukte, Land Brandenburg) was taken from the plantar site of a bulbus that showed the typical clinical appearance of DD and was transported to the laboratory immediately. It was cut into pieces of $0.5 \times 0.3 \times 0.3 \mathrm{~cm}$ and incubated in $5 \mathrm{ml}$ OMIZ (Oral Microbiologie and Immunology Zürich)-Pat medium for $1 \mathrm{~h}$ at $37^{\circ} \mathrm{C}$. This chemically defined liquid culture medium, developed by Wyss (1992), supports growth of a variety of Treponema strains (Wyss et al., 1996).

After incubation, aliquots $(100 \mu \mathrm{l})$ were mixed with $200 \mu \mathrm{l}$ fresh medium supplemented with antibiotics (rifampin and phosphomycin, 1 and $100 \mathrm{mg} \mathrm{l}^{-1}$, respectively), transferred into 96-well microtitre plates and subjected to a limit dilution procedure (Leschine \& Canale-Parola, 1980; Wyss, 1992). After $14 \mathrm{~d}$ incubation at $37^{\circ} \mathrm{C}$ in GasPak anaerobic jars (AnaeroGen), the samples were examined by dark-field microscopy (Olympus BH2-RFCA; Carl-Zeiss) to determine growth and cell morphology.

Aliquots from wells containing spirochaetes were plated onto OMIZ-Pat agar $(1.5 \%, \mathrm{w} / \mathrm{v})$ plates. Within $5-10 \mathrm{~d}$ diffuse colonies were observed within the agarose. Single colonies were streaked out onto fresh agar plates. To obtain a pure culture, the procedure was repeated three times. Afterwards the strain was removed, transferred to liquid OMIZ-Pat medium and incubated anaerobically until the late-exponential growth phase $\left(6.5 \times 10^{8}\right.$ bacteria $\left.\mathrm{ml}^{-1}\right)$ was reached. Bacteria were stored at $-80^{\circ} \mathrm{C}$ in liquid growth medium supplemented with $15 \%$ (v/v) glycerol.

Electron microscopy. For scanning electron microscopy, colony material $(1 \times 1 \mathrm{~mm})$ was fixed according to the OTOTO method (Kelley et al., 1973), dried with Peldri II (Ted Pella) and sputter-coated with gold-palladium (5 nm) (SC 501; Emscope).

For transmission electron microscopy, bacteria grown in liquid culture or material of one colony were directly applied to collodion-coated copper grids. After sedimentation of the bacteria and removal of remaining fluid, the samples were directly negatively stained by the method of Nermut (1973), or after fixation in a moist chamber with glutaraldehyde and $2 \%(\mathrm{v} / \mathrm{v})$ phosphotungstic acid for $1-5 \mathrm{~min}$. The grids were washed with PBS and double-distilled water several times and then air dried. The samples were examined with a Phillips EM 400 electron microscope.
Enzyme activities. For enzyme activity testing, $20 \mathrm{ml}$ bacteria grown in OMIZ-Pat was centrifuged $(1305 \mathrm{~g}, 10 \mathrm{~min})$. To determine catalase activity, cell pellets were covered with $3 \%(\mathrm{v} / \mathrm{v}) \mathrm{H}_{2} \mathrm{O}_{2}$ and observed for $15 \mathrm{~min}$ for bubble evolution. For API ZYM systems and Rapid ID 32A systems (bioMérieux) the cells were resuspended in double-distilled water and examined according to the manufacturer's recommendations.

SDS-gel electrophoresis. SDS-PAGE was performed by the method of Laemmli (1970). For protein pattern analysis all strains were grown in OMIZ-Pat at $37^{\circ} \mathrm{C}$. Bacteria were harvested by centrifugation $(1305 \mathrm{~g}, 10 \mathrm{~min})$. The pellet was resuspended in $100 \mu \mathrm{l}$ lysis buffer $(500 \mathrm{mM}$ Tris $/ \mathrm{HCl}$, pH 9.0; $20 \mathrm{mM}$ EDTA; $10 \mathrm{mM} \mathrm{NaCl} ; 1 \%$, w/v, SDS). The protein concentration of the lysate was determined by the method of Lowry (DC Protein Assay; Bio-Rad). An aliquot containing $10 \mu \mathrm{g}$ whole-cell protein was taken into two volumes of loading buffer, incubated for $5 \mathrm{~min}$ at $95^{\circ} \mathrm{C}$ and loaded onto an SDS-polyacrylamide $(10 \%, \mathrm{v} / \mathrm{v})$ gel. After electrophoresis the gel was stained with Coomassie brilliant blue R-250.

DNA isolation. For isolation of genomic DNA, $8 \mathrm{ml}$ treponeme culture grown to exponential phase in OMIZ-Pat was pelleted by centrifugation $\left(1305 \mathrm{~g}, 10 \mathrm{~min}, 4^{\circ} \mathrm{C}\right)$. The pellet was suspended in $100 \mu \mathrm{l}$ lysis buffer containing proteinase $\mathrm{K}$ (final concentration of $200 \mu \mathrm{g} \mathrm{ml}^{-1}$; Boehringer Mannheim) and incubated for $1 \mathrm{~h}$ at $52^{\circ} \mathrm{C}$. Phenol/chloroform extraction and all further steps have been described previously (Choi et al., 1997). Genomic DNA was resuspended in $50 \mu \mathrm{l}$ TE buffer (10 mM Tris; $1 \mathrm{mM}$ EDTA) and stored at $-20{ }^{\circ} \mathrm{C}$

165 rDNA sequencing and phylogenetic analysis. 16S rDNA was amplified by PCR using universal eubacterial primer TPU1 [5' AGAGTTTGATC(A/C)TGGCTCAG 3'; corresponding to positions 8-27 in Escherichia coli $16 \mathrm{~S}$ rRNA] and biotinylated eubacterial primer RTU8 [5' AAGGAGGTGATCCA(T/G)CC(G/A)CA 3' ; corresponding to positions $1541-1522$ in $E$. coli $16 \mathrm{~S}$ rRNA] as described previously (Choi et al., 1994). For sequence determination of the reverse strand, primer RTU8 and biotinylated primer TPU1 were used to amplify the appropriate almost full-length $16 \mathrm{~S}$ rDNA fragment. Biotinylated strands were separated by using streptavidin-coated paramagnetic beads (Dynabeads; Dynal Hamburg). Infrared labelled universal eubacterial primers were used as sequencing primers (Lane et al., 1985; Weisburg et al., 1991). A Thermo Sequenase fluorescencelabelled primer cycle sequencing kit (Amersham) and a model 4000 LI-COR automated sequencer (MWG-Biotech) were used according to the manufacturers' instructions.

The 16S rDNA sequence of the new isolate was compared with those of all currently available sequences from the public databases (EMBL, GenBank) using the sequence analysis program Husar 4.0 (Deutsches Krebsforschungszentrum, Heidelberg, Germany). For phylogenetic analysis the TREECON version 3.1 software package was used (van de Peer \& de Wachter, 1993). A phylogenetic tree was constructed using the neighbour-joining method of Saitou \& Nei (1987). Multiple base changes at single positions were corrected by the method of Jukes \& Cantor (1969). All positions were included in the distance calculation.

Phylotype-specific rDNA-based oligonucleotide probe. Specific oligonucleotide probe DDK 5/3 (5' CCTCACAGCTCTCTAACCTC $3^{\prime}$; corresponding to positions 184-204 in E. coli $16 \mathrm{~S}$ rRNA) was designed. The specificity of probe DDK $5 / 3$ was assessed by dot-blot hybridization using PCRamplified 16S rDNA from 34 related and unrelated bacteria. 

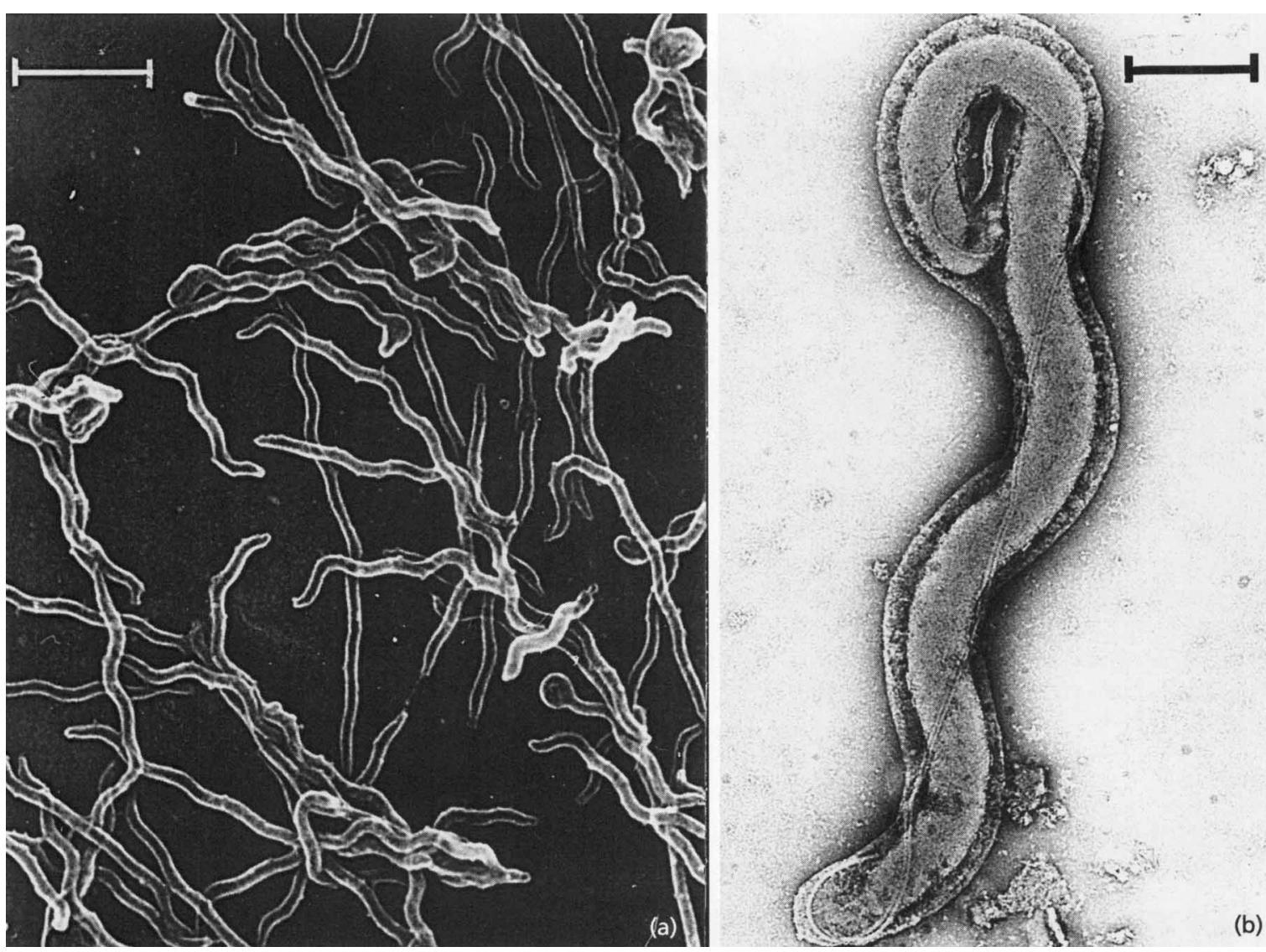

Fig. 1. (a) Scanning electron micrograph of strain $D D 5 / 3^{\top}$ cells grown in liquid medium. Different morphotypes are visible: cells with loose irregular windings and helical and circular forms. Bar, $2 \mu \mathrm{m}$. (b) Transmission electron micrograph of a cell of strain DD $5 / 3^{\top}$ with the outer cell membrane visible. The two periplasmic flagella are subterminally attached at each pole. The preparation was negatively stained. Bar, $0.5 \mu \mathrm{m}$.

The controls included sequences from uncultured oral treponemes derived from a $16 \mathrm{~S}$ rDNA library, culturable Treponema species and oral pathogens as described by Moter et al. (1998). This probe was used to identify the appropriate organisms by fluorescence in situ hybridization (FISH).

FISH. For FISH, bacteria were grown in OMIZ-Pat, pelleted by centrifugation $\left(4000 \mathrm{~g}, 5 \mathrm{~min}, 4^{\circ} \mathrm{C}\right.$; Heraeus Labofuge 400 ) and washed in cold PBS. Fixation and preparation of bacteria were performed as described previously (Gersdorf et al., 1993), except the final methanol and formaldehyde fixation step was omitted. The oligonucleotide DDK5/3 was enzymically labelled at the $3^{\prime}$ end with Cy3 (indocarbocyanin)-dUTP (Amersham) by using terminal transferase according to the digoxigenin-labelling protocols (Boehringer Mannheim) and hybridization was performed as described previously (Choi et al., 1997). ' $T$. vincentii', T. maltophilum, ' $T$. phagedenis', $T$. denticola $\mathrm{CD}-1$ and $E$. coli served as negative control strains to assess specifity of probe DDK5/3. Control strains were included in every in situ hybridization experiment.

The FISH preparations were examined under oil immersion with a $\times 100$ Neofluar objective on an Axioskop epifluorescence microscope (Carl-Zeiss) equipped with a highpressure mercury bulb (HBO 50, Osram) and narrow-band filter sets HQ-F41-007 and HQ-F41-001 (AHF). Photo- micrographs were taken on a Kodak Ektachrome HC 400 film.

Nucleotide sequence accession numbers. The EMBL accession numbers for the reference spirochaetal 16S rRNA sequences used in this study are as follows: Treponema medium, Y09959; DDKL-13, Y08896; ' $T$. phagedenis', M57739; DDKL-4, Y08894; T. denticola, M71236; DDKL3, Y08893; Treponema pallidum, M88726; Spirochaeta sp., $\mathrm{M} 71240 ; T$. maltophilum, X87140; T. pectinovorum, M71237; Treponema bryantii, M57737; Treponema saccharophilum, M71238; Treponema sp., M59294; Treponema succinifaciens, M57738; Spirochaeta aurantia, M57740; Spirochaeta isovalerica, M88720; Borrelia burgdorferi, L36160; Borrelia anserina, M72397; Borrelia hermsii, M60968; Brachyspira aalborgi, Z22781 ; Brachyspira (formerly Serpulina) hyodysenteriae, M57742; Brachyspira (formerly Serpulina) innocens, M57744; Leptonema illini, Z21632; Leptospira biflexa, Z12821; Leptospira interrogans, X17547; isolate 1-9185MED, L78125; isolate 2-1498, L78126; E. coli, J01859.

\section{RESULTS}

\section{Cultural and morphological characteristics}

Using a chemically defined culture medium, OMIZPat, we isolated by limit dilution a novel small spirochaete. The strain was isolated from a biopsy of a 
dairy cow with clinical appearance typical for $\mathrm{DD}$. The temperature for growth of the new isolate was $37^{\circ} \mathrm{C}$ in GasPak anaerobic jars. After $5 \mathrm{~d}$ incubation the strain formed small white diffuse colonies with a diameter up to $3 \mathrm{~mm}$ that penetrated completely into the agar on OMIZ-Pat agar plates.

The cells were $5-8 \mu \mathrm{m}$ long and $0 \cdot 25-0 \cdot 55 \mu \mathrm{m}$ wide, as shown in Fig. 1. They had a cytoplasmic cylinder surrounded by two periplasmic flagella that originated subterminally at each pole.

In liquid medium the cells exhibited high motility. The cells varied in length depending upon the age of the culture. No growth was seen under aerobic conditions. At a growth temperature of $37^{\circ} \mathrm{C}$ the culture reached maximum cell density $\left(8 \times 10^{8}\right.$ bacteria $\left.\mathrm{ml}^{-1} ; \mathrm{pH} 5.5\right)$ after $21 \mathrm{~h}$ incubation, whereas the cell density at the beginning was $8.5 \times 10^{6}$ bacteria $\mathrm{ml}^{-1} ; \mathrm{pH} \mathrm{6.9}$. In the stationary phase of liquid culture the cells developed circular forms (Fig. 2b). The addition of $2-10 \%(\mathrm{v} / \mathrm{v})$ rabbit serum or a growth temperature of $30^{\circ} \mathrm{C}$ resulted in a decreased growth rate and the serum has therefore been omitted.

\section{Protein profile}

The protein profile of the new isolate exhibited major bands in the region between 31 and $66 \mathrm{kDa}$ (Fig. 3).

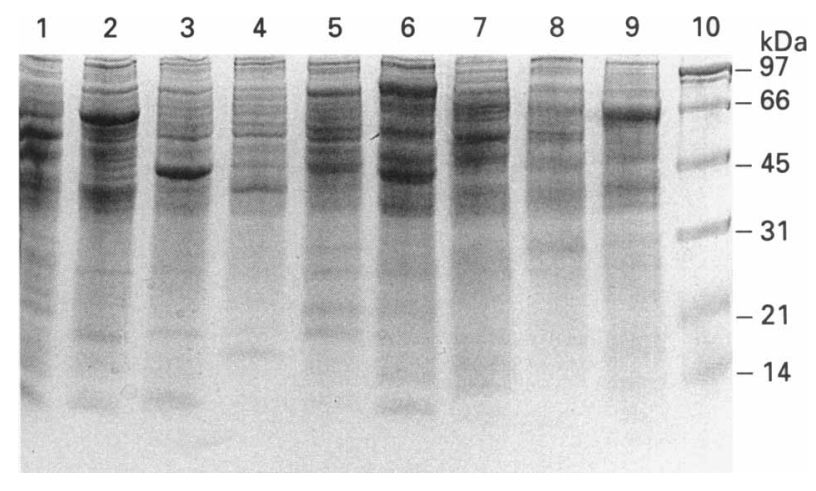

Fig. 3. Coomassie-stained polypeptide patterns of whole cells of novel strain DD5/3 ${ }^{\top}$ and of representative strains of eight cultivable treponemes on an SDS-10\% polyacrylamide gel. Lanes: 1 , strain DD5/3 $; 2$, T. maltophilum ATCC $51939^{\top} ; 3, T$. socranskii subsp. socranskii ATCC $35536^{\mathrm{T}}$; 4, T. socranskii subsp. paredis ATCC $35535^{\top} ; 5, T$. socranskii subsp. buccale ATCC $35534^{\top} ; 6, T$. pectinovorum ATCC $33768^{\top} ; 7, T$. denticola CD-1; 8, 'T. vincentii' LA-1; 9, 'T. phagedenis' biotype Reiter; 10, molecular mass standards (in $\mathrm{kDa}$ ).

These were clearly different from those of the reference strains $T$. denticola, $T$. pectinovorum, $T$. socranskii subsp. buccale, T. socranskii subsp. paredis, T. socranskii subsp. socranskii, 'T. vincentii', T. maltophilum,
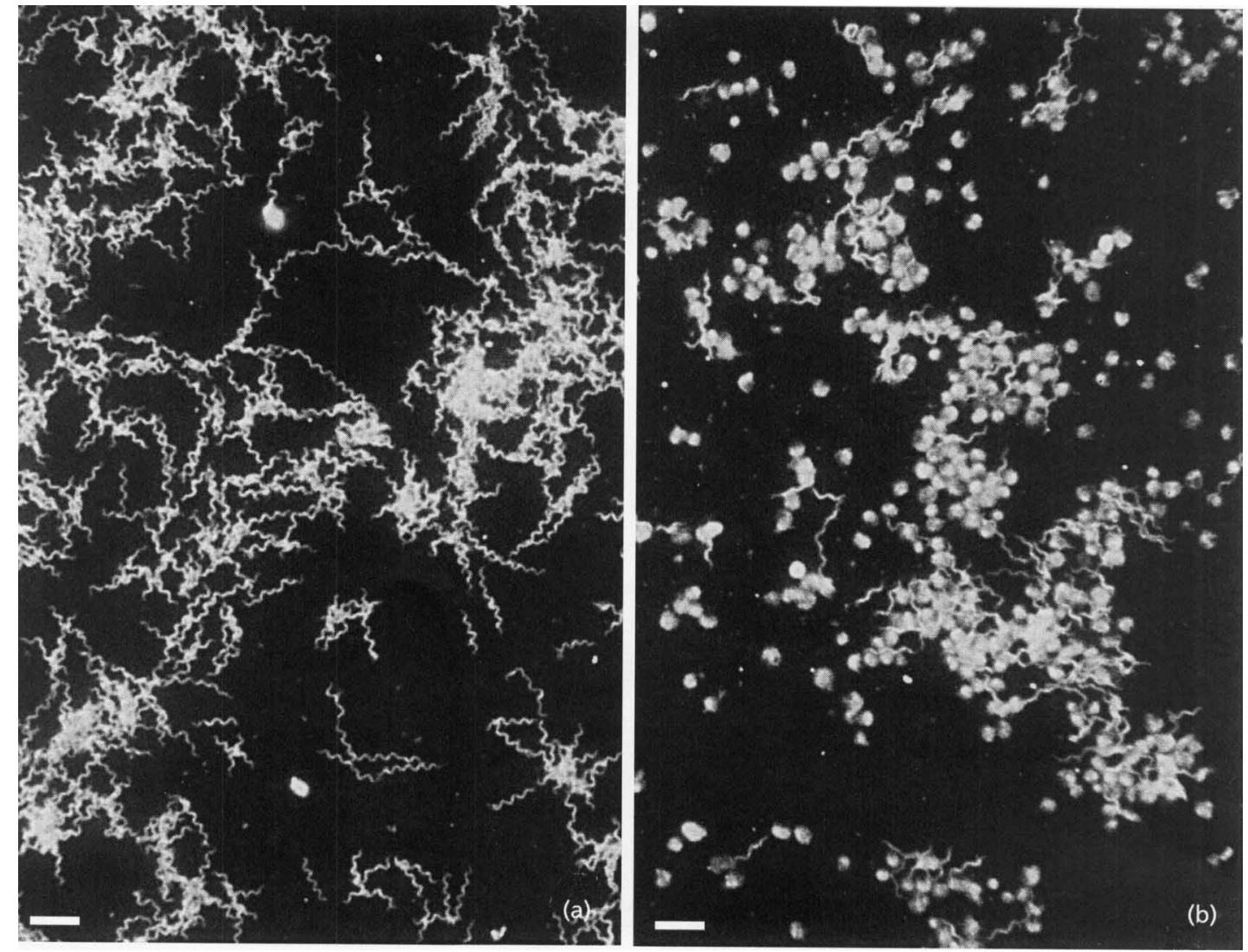

Fig. 2. FISH analysis of strain $D D 5 / 3^{\top}$ cultures grown to exponential (a) and stationary (b) phase using the specific oligonucleotide probe DDK5/3. Hybridization clearly showed helical forms (a) and circular forms (b) of the novel strain. Bar, $5 \mu \mathrm{m}$. 
Table 1. Enzyme activities in treponemes as determined by the API ZYM system

Enzymes: 1, alkaline phosphatase; $2, \mathrm{C}_{4}$ esterase; $3, \mathrm{C}_{8}$ esterase lipase; $4, \mathrm{C}_{14}$ lipase ; 5 , leucine arylamidase; 6 , valine arylamidase ; 7 , cystine arylamidase; 8 , trypsin; 9 , chymotrypsin; 10 , acid phosphatase; 11 , naphtholphosphohydrolase; $12, \alpha$ galactosidase; $13, \beta$-galactosidase; $14, \beta$-glucuronidase; $15, \alpha$-glucosidase; $16, \beta$-glucosidase; $17, N$-acetyl- $\beta$-glucosaminidase; 18 , $\alpha$-mannosidase; $19, \alpha$-fucosidase.

\begin{tabular}{|c|c|c|c|c|c|c|c|c|c|c|c|c|c|c|c|c|c|c|c|c|c|}
\hline \multirow[t]{2}{*}{ Taxon } & \multirow[t]{2}{*}{ Strain } & \multirow[t]{2}{*}{ Source } & \multicolumn{19}{|c|}{ Enzyme activity } \\
\hline & & & 1 & 2 & 3 & 4 & 5 & 6 & 7 & 8 & 9 & 10 & 11 & 12 & 13 & 14 & 15 & 16 & 17 & 18 & 19 \\
\hline Novel isolate & $\mathrm{DD} 5 / 3^{\mathrm{T}}$ & & + & + & + & - & - & - & - & - & - & + & + & - & + & - & + & - & + & - & - \\
\hline \multirow{2}{*}{ Veterinary treponemes } & Isolates* & $\dagger$ & + & + & + & - & - & - & - & - & - & + & + & - & + & + & - & - & + & - & - \\
\hline & 1-9185MED & $\dagger$ & + & + & + & - & - & - & - & + & + & + & + & - & - & - & - & - & - & - & - \\
\hline \multirow[t]{3}{*}{ T. maltophilum } & $\mathbf{B R}^{\mathrm{T}}$ & $\ddagger$ & + & + & + & - & - & - & - & - & - & + & + & + & - & - & + & - & - & - & + \\
\hline & $\mathrm{HO} 2 \mathrm{~A}$ & $\dagger$ & + & + & + & - & - & - & - & - & - & + & + & + & + & + & + & + & - & - & - \\
\hline & PNA1 & $\ddagger$ & + & + & + & - & - & - & - & - & - & + & + & + & + & - & + & + & - & - & - \\
\hline \multirow[t]{2}{*}{ T. denticola } & $\mathrm{CD}-1$ & $\ddagger$ & + & + & + & - & + & - & - & + & + & + & + & + & - & - & - & - & - & - & - \\
\hline & $51 \mathrm{~B} 2$ & $\ddagger$ & + & + & + & - & + & - & + & + & + & + & + & + & + & - & - & + & - & - & - \\
\hline$T$. pectinovorum & ATCC $33768^{\mathrm{T}}$ & $\ddagger$ & - & + & + & - & - & - & - & - & - & + & + & - & - & - & - & - & - & - & - \\
\hline $\begin{array}{l}\text { T. socranskii subsp. } \\
\text { buccale }\end{array}$ & ATCC $35534^{\mathrm{T}}$ & $\ddagger$ & + & + & + & - & - & - & - & - & - & + & + & - & - & + & - & - & - & - & - \\
\hline $\begin{array}{l}T \text {. socranskii subsp. } \\
\text { paredis }\end{array}$ & ATCC $35535^{\mathrm{T}}$ & $\ddagger$ & + & + & + & - & - & - & - & - & - & + & + & - & - & - & - & - & - & - & - \\
\hline $\begin{array}{l}\text { T. socranskii subsp. } \\
\text { socranskii }\end{array}$ & ATCC $35536^{\mathrm{T}}$ & $\ddagger$ & + & + & - & - & - & - & - & - & - & + & + & - & - & - & - & - & - & - & - \\
\hline \multirow[t]{2}{*}{ ' $T$. vincentii' } & LA-1 & $\ddagger$ & - & - & - & - & + & - & - & - & - & + & + & - & + & - & - & - & + & - & - \\
\hline & Ritz A & $t$ & - & + & + & - & + & - & - & - & - & + & + & - & + & - & - & - & + & - & - \\
\hline T. amylovorum & & $\S$ & + & + & - & - & - & - & - & - & - & + & + & - & - & - & - & - & - & - & + \\
\hline
\end{tabular}

* All published isolates except 1-9185MED.

†Walker et al. (1995).

† Wyss et al. (1996).

$\S$ Wyss et al. (1997).

' $T$. phagedenis' biotype Reiter (Fig. 3). These results demonstrate that the new isolate, designated Treponema brennaborense, could be clearly distinguished from the reference species by its protein pattern.

\section{Enzyme activities}

In Table 1 phenotypic characteristics of strain DD5 $/ 3^{T}$ as detected by the API ZYM system are shown in comparison with the enzyme activities of cultivated oral treponemes, described by Wyss et al. $(1996,1997)$, and DD treponemes, as published by Walker et al. (1995). The following enzyme activities were found: alkaline phosphatase, $\mathrm{C}_{4}$ esterase, $\mathrm{C}_{8}$ esterase lipase, acid phosphatase, naphtholphosphohydrolase, $\beta$ galactosidase, $\alpha$-glucosidase and $N$-acetyl- $\beta$-glucosaminidase. Using the Rapid ID 32A system, the new isolate exhibited the enzyme activities alkaline phosphatase, $\beta$-galactosidase, $\alpha$-glucosidase, $N$-acetyl- $\beta$ glucosaminidase and arginine arylamidase and it fermented raffinose and mannose. The catalase test was negative.

\section{Phylogenetic classification}

The almost complete $16 \mathrm{~S}$ rRNA sequence (1400 bases) was determined for phylogenetic classification. Comparative $16 \mathrm{~S}$ rDNA sequence analysis showed highest homology to (cluster 17) group IV oral treponemes according to the phylogenetic tree derived from a periodontitis patient (Choi et al., 1994) The new strain showed sequence similarity of $89.5 \%$ to $T$. maltophilum, the as yet only cultured species of group IV (Fig. 4).

The overall levels of sequence similarity between $T$. brennaborense $16 \mathrm{~S}$ rRNA and those of other cultivable oral treponemes ranged from 83.7 to $89.5 \%$ (Table 2 ).

\section{FISH}

Among all cultivable treponeme species tested, oligonucleotide probe DDK5/3 specifically detected the novel isolate. FISH analysis showed helical (Fig. 2a) and circular (Fig. 2b) forms of strain DD5 $/ 3^{\mathrm{T}}$. 


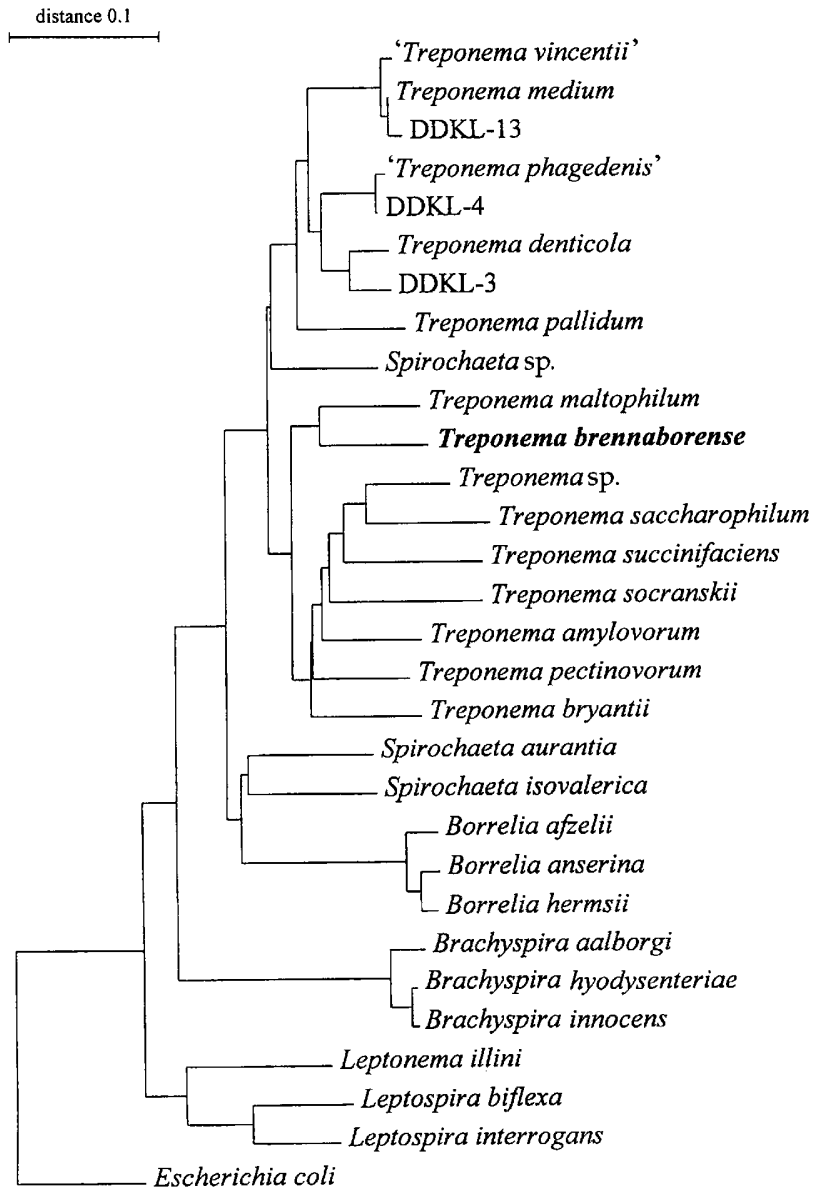

Fig. 4. Phylogenetic tree showing the relationship of novel strain $D D 5 / 3^{\top}$ to other spirochaetes based on a comparison of $16 S$ rRNA sequences (positions 67-1467 in E. coli $16 \mathrm{~S}$ rRNA). $E$. coli was used as the outgroup. Scale bar, $10 \%$ difference in nucleotide sequences as determined by measuring the lengths of the horizontal lines connecting two sequences. DDKL sequences were obtained from cloned PCR products of uncultured bacteria.

\section{DISCUSSION}

The aetiology of DD, a chronic ulcerative epidermitis of the feet of cattle, is still under discussion. A variety of bacterial species including anaerobic Gram-negative rods have been isolated from DD lesions. However, spirochaetes appear to be the predominant organisms in DD lesions and they have been found to invade the stratum spinosum and dermal papillae (Kimura et al., 1993; Read et al., 1992). Microscopic analysis of touch preparations of infected tissue showed different spirochaetal morphotypes (Choi et al., 1997; Done et al., 1993; Döpfer et al., 1997; Read et al., 1992). A report of a significant humoral response in cattle suffering from DD, as compared to healthy animals without detectable lesions, further suggested a possible role of spirochaetes in the aetiopathogenesis of DD (Walker et al., 1997).

Because of the fastidious nature of spirochaetes only few strains associated with DD in cattle have been cultured so far (Walker et al., 1995). Based upon their enzyme activities and morphological or antigenic characteristics, which were clearly different from those of known spirochaetes, they were classified as members of the genus Treponema (Walker et al., 1995). Recently, we used comparative $16 \mathrm{~S}$ rDNA analysis to phylogenetically classify DD spirochaetes. All of the spirochaetal sequences of a DD-specific 16S rDNA library clustered within the genus Treponema and were closely related to oral treponemes (Choi et al., 1997).

Here we present data of a novel isolate, derived from a DD lesion of an infected cattle, including biochemical, enzymic, morphological and phylogenetic comparisons to known spirochaetes.

By using culture media developed primarily for the isolation of oral spirochaetes, we successfully cultivated treponemes from DD material. After cloning by limit dilution we obtained an isolate with typical spirochaetal morphology and motility. Electron microscopic analysis showed the presence of a cytoplasmic cylinder and two periplasmic endoflagella, inserting subterminally at each pole. Strain DD5 $/ 3^{\mathrm{T}}$ could be clearly distinguished by its flagellation type from all but one (strain 1-9185MED) of the isolates described by Walker et al. (1995). In addition, all isolates differed by their enzyme activities from our new strain (Table 1). This was also true for strain 1-9185MED, which exhibited trypsin and chymotrypsin activity, but lacked $\beta$-galactosidase, $\alpha$-glucosidase and $N$-acetyl- $\beta$ glucosaminidase activity. None of the oral treponeme species showed an identical enzyme pattern in the API ZYM system (Table 1). Furthermore, the novel isolate showed a different protein pattern compared to all treponemes investigated (Fig. 3).

Comparative 16S rDNA sequence analysis allowed the unambiguous phylogenetic classification of the new isolate as a member of the genus Treponema, different from all strains published by Walker et al. (1995). The data of the similarity matrix constructed from the sequence of strain DD5 $/ 3^{\mathrm{T}}$ and those of 17 other spirochaetes clearly support the species status of the new isolate. As seen in Table 2 our strain exhibited highest homology $(89.5 \%)$ to T. maltophilum, recently isolated from human subgingival plaque (Wyss et al., 1996).

Multiple sequence alignment allowed us to design an oligonucleotide probe specific for the new strain. The specificity of the probe was tested using FISH on different treponeme cultures. Using FISH and electron microscopic analysis on a $T$. brennaborense culture, circular morphotypes were detected (Fig. 2b). These forms were primarily found in older cultures of DD isolates (Walker et al., 1995) and other treponeme species (Walker et al., 1995; Wecke et al., 1995; Wolf et al., 1993; Wolf \& Wecke, 1994). However, the mechanisms leading to circular forms and their possible biological role are still unknown. 
Table 2. $16 \mathrm{~S}$ rRNA sequence similarity matrix for novel treponeme strain $\mathrm{DD} 5 / 3^{\top}$ and reference organisms

The similarity values were determined by sequence pair comparison.

\begin{tabular}{|c|c|c|c|c|c|c|c|c|c|c|c|c|c|c|c|c|c|c|c|}
\hline \multirow[t]{2}{*}{ Taxon } & \multirow{2}{*}{$\begin{array}{c}\text { Phylogenetic } \\
\text { group }\end{array}$} & \multicolumn{18}{|c|}{ 16S rRNA similarity (\%) } \\
\hline & & 1 & 2 & 3 & 4 & 5 & 6 & 7 & 8 & 9 & 10 & 11 & 12 & 13 & 14 & 15 & 16 & 17 & 18 \\
\hline $\mathbf{1} ' T$. vincentii' & I & & & & & & & & & & & & & & & & & & \\
\hline 2 DDKL-13* & $x$ & $98 \cdot 7$ & & & & & & & & & & & & & & & & & \\
\hline $3 T$. medium & I & $98 \cdot 8$ & $99 \cdot 6$ & & & & & & & & & & & & & & & & \\
\hline 4 'T. phagedenis' & & 91.0 & $91 \cdot 3$ & $91 \cdot 4$ & & & & & & & & & & & & & & & \\
\hline 5 DDKL-4* & & 90.6 & $91 \cdot 2$ & $91 \cdot 4$ & $99 \cdot 4$ & & & & & & & & & & & & & & \\
\hline $6 T$. denticola & II & $90 \cdot 4$ & $91 \cdot 4$ & $91 \cdot 6$ & $92 \cdot 3$ & 93.0 & & & & & & & & & & & & & \\
\hline 7 DDKL-3* & II & $89 \cdot 3$ & $90 \cdot 2$ & $90 \cdot 4$ & 92.0 & $92 \cdot 1$ & $95 \cdot 3$ & & & & & & & & & & & & \\
\hline 8 T. pallidum & & 87.6 & 87.7 & $87 \cdot 7$ & $90 \cdot 4$ & $90 \cdot 5$ & $89 \cdot 4$ & $89 \cdot 1$ & & & & & & & & & & & \\
\hline $9 T$. maltophilum & IV & 86.6 & $86 \cdot 3$ & 86.9 & $86 \cdot 4$ & $86 \cdot 3$ & $87 \cdot 2$ & $87 \cdot 1$ & $84 \cdot 5$ & & & & & & & & & & \\
\hline 10 Strain $\mathrm{DDS} / 3^{\mathrm{T}}$ & IV & 87.5 & 87.5 & 88.0 & $85 \cdot 9$ & $86 \cdot 3$ & $87 \cdot 3$ & $86 \cdot 6$ & $84 \cdot 2$ & $89 \cdot 5$ & & & & & & & & & \\
\hline 11 T. bryantii & & $85 \cdot 0$ & $83 \cdot 9$ & $84 \cdot 4$ & 84.8 & $84 \cdot 4$ & $85 \cdot 1$ & $85 \cdot 7$ & $84 \cdot 2$ & $86 \cdot 4$ & $87 \cdot 0$ & & & & & & & & \\
\hline $12 T$, pectinovorum & & $84 \cdot 5$ & $85 \cdot 1$ & $85 \cdot 5$ & $84 \cdot 6$ & $85 \cdot 1$ & $85 \cdot 4$ & $85 \cdot 4$ & $84 \cdot 1$ & 87.9 & $89 \cdot 2$ & $87 \cdot 0$ & & & & & & & \\
\hline $13 T$. amylovorum & & $82 \cdot 8$ & $83 \cdot 2$ & $83 \cdot 8$ & $84 \cdot 2$ & 83.7 & $84 \cdot 8$ & $84 \cdot 3$ & 83.0 & $85 \cdot 6$ & $86 \cdot 9$ & 86.8 & $88 \cdot 5$ & & & & & & \\
\hline $14 T$. succinifaciens & & $79 \cdot 5$ & $79 \cdot 8$ & $80 \cdot 5$ & $80 \cdot 8$ & $81 \cdot 5$ & $81 \cdot 0$ & $80 \cdot 9$ & 82.6 & $81 \cdot 3$ & $83 \cdot 7$ & 83.5 & $83 \cdot 6$ & $85 \cdot 5$ & & & & & \\
\hline 15 Treponema sp. & & $82 \cdot 2$ & $83 \cdot 4$ & $83 \cdot 7$ & $83 \cdot 9$ & $83 \cdot 5$ & 83.8 & $83 \cdot 6$ & $84 \cdot 7$ & $84 \cdot 6$ & $85 \cdot 2$ & $86 \cdot 0$ & $86 \cdot 6$ & 86.2 & $88 \cdot 2$ & & & & \\
\hline $16 T$. saccharophilum & & $82 \cdot 4$ & 83.6 & $84 \cdot 1$ & $82 \cdot 9$ & $83 \cdot 2$ & $83 \cdot 7$ & 83.9 & $82 \cdot 8$ & $82 \cdot 7$ & $83 \cdot 7$ & $83 \cdot 6$ & $86 \cdot 2$ & 83.5 & $82 \cdot 7$ & 87.9 & & & \\
\hline $17 T$. socranskii & & $82 \cdot 8$ & $82 \cdot 1$ & $82 \cdot 8$ & 83.8 & 83.8 & $84 \cdot 2$ & $82 \cdot 8$ & $82 \cdot 9$ & $83 \cdot 9$ & 83.8 & $84 \cdot 1$ & $84 \cdot 9$ & $86 \cdot 6$ & $83 \cdot 9$ & $85 \cdot 1$ & $81 \cdot 3$ & & \\
\hline 18 Spirochaeta sp. & & 87.6 & $87 \cdot 6$ & $88 \cdot 3$ & $86 \cdot 1$ & $87 \cdot 5$ & 87.0 & $87 \cdot 9$ & $87 \cdot 0$ & $85 \cdot 2$ & 87.0 & $85 \cdot 3$ & $83 \cdot 9$ & 84.9 & $82 \cdot 4$ & $84 \cdot 9$ & 83.0 & $83 \cdot 2$ & \\
\hline
\end{tabular}

* 16S rDNA clone sequences (Choi et al., 1997).

At present, we have no information about the epidemiology of this species. Interestingly, the new isolate was most closely related to the phylogenetic group IV of oral treponemes but was not found in our DDspecific 16S rDNA library published earlier (Choi et al., 1997), suggesting a higher diversity of DD treponemes as compared to oral treponemes in human periodontitis. Molecular epidemiological analyses using the specific oligonucleotide probe are needed to provide information about the incidence and distribution of $T$. brennaborense in DD-infected animals. Phenotypic characteristics and 16S rDNA gene sequence data indicate that $\mathrm{DD} 5 / 3^{\mathrm{T}}$ represents a new species for which we propose the name Treponema brennaborense.

\section{Description of Treponema brennaborense sp. nov.}

Treponema brennaborense (bren.na.bo.ren'se. Brennabor, medieval name of Brandenburg, Germany; $M$. L. neut. adj. brennaborense referring to Brennabor, where the cow was raised from which the organism was first isolated).

Anaerobic, Gram-negative, helically coiled, motile treponeme isolated from a DD biopsy of a dairy cow. Bacterial cells are 5-8 $\mu \mathrm{m}$ long and $2 \cdot 5-5.5 \mu \mathrm{m}$ wide. They have a cytoplasmic cylinder and two periplasmic flagella that originate subterminally at each cell pole. In stationary-phase liquid cultures the bacteria develop circular forms. In liquid culture the bacteria exhibit rotational movement. Growth of strain DD5 $/ 3^{\mathrm{T}}$ is accompanied by acid production. The optimum growth temperature is $37^{\circ} \mathrm{C}$ and maximum cell density of approximately $8 \times 10^{8}$ bacteria $\mathrm{ml}^{-1}$ is reached after $21 \mathrm{~h}$ incubation. Cells can be stored frozen $\left(-80^{\circ} \mathrm{C}\right)$ in OMIZ-Pat medium supplemented with $15 \%(\mathrm{v} / \mathrm{v})$ glycerol. Using semi-solid agarose plates $T$. brennaborense forms diffuse, submersed white colonies up to $3 \mathrm{~mm}$ in diameter within $5 \mathrm{~d}$ incubation. Strain DD5 $/ 3^{\mathrm{T}}$ ferments raffinose and mannose and exhibits the enzyme activities alkaline phosphatase, $\mathrm{C}_{4}$ esterase, $\mathrm{C}_{8}$ esterase lipase, acid phosphatase, naphtholphosphohydrolase, $\beta$-galactosidase, $\alpha$-glucosidase, $N$ acetyl- $\beta$-glucosaminidase and arginine arylamidase, as determined by the API ZYM and Rapid ID 32A systems. Catalase is not produced. The addition of $2-10 \%(\mathrm{v} / \mathrm{v})$ rabbit serum leads to decreased growth rate. The strain is resistant to rifampin $\left(1 \mathrm{mg} \mathrm{l}^{-1}\right)$ and phosphomycin $\left(100 \mathrm{mg} \mathrm{l}^{-1}\right)$. Strain DD5/3 $3^{\mathrm{T}}$ is designated the type strain and has been deposited in the Deutsche Sammlung von Mikroorganismen und Zellkulturen (DSMZ, Braunschweig, Germany) as DSM $12168^{\mathrm{T}}$.

Distinguishing characteristics. All previously described treponemes are genetically distinct from $T$. brennaborense as determined by comparative $16 \mathrm{~S}$ rDNA sequencing. $T$. brennaborense could be clearly distinguished by its morphology, protein pattern and enzyme activities from the other cultivable Treponema species. Its flagellation type was different from most of the other cultivable Treponema species. Only $T$. denticola, $T$. pectinovorum, veterinary isolate 1-9185MED and $T$. maltophilum exhibited the same flagellation type, but they exhibited different enzyme activities. Furthermore T. brennaborense is distinguishable from $T$. maltophilum by its lack of $\alpha$-galactosidase activity and its $N$-acetyl- $\beta$-glucosaminidase activity. T. brennaborense is clearly distinguishable from veterinary isolate 1-9185MED by its lack of trypsin and chymotrypsin activities. 


\section{ACKNOWLEDGEMENTS}

We thank M. Kachler for excellent technical assistance and J. Gatzmann for the electron microscopy. This study was supported in part by a grant (01KI9318) from the Bundesministerium für Bildung und Forschung to U.B.G.

\section{REFERENCES}

Blowey, R. W. \& Sharp, M. W. (1988). Digital dermatitis in dairy cattle. Vet Rec 122, 505-508.

Cheli, R. \& Mortellaro, C. (1974). La dermatide digitale del bovino. In Proceedings of the 8th International Conference on Diseases of Cattle, Milan, pp. 208-213.

Choi, B.-K., Paster, B. J., Dewhirst, F. E. \& Göbel, U. B. (1994). Diversity of cultivable and uncultivable oral spirochetes from a patient with severe destructive periodontitis. Infect Immun 62, 1889-1895.

Choi, B.-K., Nattermann, H., Grund, S., Haider, W. \& Göbel, U. B. (1997). Spirochetes from digital dermatitis lesions in cattle are closely related to treponemes associated with human periodontitis. Int J Syst Bacteriol 47, 175-181.

Collighan, R. J. \& Woodward, M. J. (1997). Spirochaetes and other bacterial species associated with bovine digital dermatitis. FEMS Microbiol Lett 156, 37-41.

Done, S. H., Blowey, R. W. \& Cooley, W. (1993). The pathology of digital dermatitis in cattle in the UK. In Proceedings of the American Association of Veterinary Laboratory Diagnosticians Meeting, Las Vegas, NV, USA, p. 69.

Döpfer, D., Koopmans, A., Meijer, F. A. \& 7 other authors (1997). Histological and bacteriological evaluation of digital dermatitis in cattle, with special reference to spirochaetes and Campylobacter faecalis. Vet Rec 140, 620-623.

Gersdorf, H., Pelz, K. \& Göbel, U. B. (1993). Fluorescence in situ hybridization for direct visualisation of Gram-negative anaerobes in subgingival plaque samples. FEMS Immunol Med Microbiol 6, 109-114.

Grund, S., Nattermann, H. \& Horsch, F. (1995). Zum elektronenmikroskopischen Spirochäten-Nachweis bei der Dermatitis digitalis des Rindes. J Vet Med 42, 533-542.

Jukes, T. H. \& Cantor, C. R. (1969). Evolution of protein molecules. In Mammalian Protein Metabolism, pp. 21-132. Edited by H. N. Munro. New York: Academic Press.

Kelley, R. O., Dekker, R. A. F. \& Bluemink, J. G. (1973). Ligandmediated osmium binding: its application in coating biological specimens for scanning electron microscopy. $J$ Ultrastruct Res 45, 254-258.

Kimura, Y., Takahashi, M., Matsumoto, N. \& 8 other authors (1993). Verrucose dermatitis and digital papillomatosis in dairy cows. J Vet Med Jpn 46, 899-906.

Laemmli, U. K. (1970). Cleavage of structural proteins during the assembly of the head of bacteriophage T4. Nature 227, 680-685.

Lane, D. J., Pace, B., Olsen, G. J., Stahl, D. A., Sogin, M. L. \& Pace, N. R. (1985). Rapid determination of $16 \mathrm{~S}$ ribosomal RNA sequences for phylogenetic analysis. Proc Natl Acad Sci USA 82, 6955-6959.

Leschine, S. B. \& Canale-Parola, E. (1980). Rifampicin as a selective agent for isolation of oral spirochetes. J Clin Microbiol 12, 792-795.

Moter, A., Hoenig, C., Choi, B.-K., Riep, B. \& Göbel, U. B. (1998). Molecular epidemiology of oral treponemes in periodontal disease. J Clin Microbiol 36, 1399-1403.

Nattermann, H., Grund, S., Ehrlich, M., Zucker, B., Choi, B.-K. \& Göbel, U. B. (1996). Zur Ätiologie der Dermatitis Digitalis des Rindes. In Tagung der Deutschen Vet Gesellschaft, Fachgruppe Bakteriologie und bakterielle Krankheiten, pp. 345-351.

Nermut, M. V. (1973). Methoden der Negativ-Kontrastierung. In Methodensammlung der Elektronenmikroskopie, pp. 1-18. Edited by G. Schimmel \& W. Vogell. Stuttgart: Wisseuschaftlicher.

van de Peer, Y. \& de Wachter, R. (1993). TREECON: a software package for the construction and drawing of evolutionary trees. Comput Appl Biosci 9, 177-182.

Read, D. H., Walker, R. L., Castro, A. E., Sundberg, J. P. \& Thurmond, M. C. (1992). An invasive spirochete associated with interdigital papillomatosis of dairy cattle. Vet Rec 130, 59-60.

Rijpkema, S. G. T., David, G. P., Hughes, S. L. \& Woodward, M. J. (1997). Partial identification of spirochaetes from two dairy cows with digital dermatitis by polymerase chain reaction analysis of the 16S ribosomal RNA gene. Vet Rec 140, 257-259.

Saitou, N. \& Nei, M. (1987). The neighbor-joining method: a new method for reconstructing phylogenetic trees. Mol Biol Evol 4, $406-425$.

Walker, R. L., Read, D. H., Loretz, K. J. \& Nordhausen, R. W. (1995). Spirochetes isolated from dairy cattle with papillomatous digital dermatitis and interdigital dermatitis. Vet Microbiol 47, 343-355.

Walker, L. R., Read, D. H., Loretz, K. J., Hird, D. W. \& Berry, S. L. (1997). Humoral response of dairy cattle to spirochetes isolated from papillomatous digital dermatitis lesions. Am J Vet Rec $\mathbf{5 8}$, 744-748.

Wecke, J., Wolf, V., Fath, S. \& Bernimoulin, J.-P. (1995). The occurrence of treponemes and their spherical bodies on polytetrafluoroethylene membranes. Oral Microbiol Immunol 10, 278-283.

Weisburg, W. G., Barns, S. M., Pelletier, D. A. \& Lane, D. J. (1991). 16S ribosomal DNA amplification for phylogenetic study. $J$ Bacteriol 173, 697-703.

Wolf, V. \& Wecke, J. (1994). Formation of multiple treponemes. Zentbl Bakteriol 280, 297-303.

Wolf, V., Lange, R. \& Wecke, J. (1993). Development of quasimulticellular bodies of Treponema denticola. Arch Microbiol 160, 206-213.

Wyss, C. (1992). Growth of Porphyromonas gingivalis, Treponema denticola, $T$. pectinovorum, $T$. socransckii, and $T$. vincentii in a chemically defined medium. J Clin Microbiol 30, 2225-2229.

Wyss, C., Choi, B.-K., Schüpbach, P., Guggenheim, B. \& Göbel, U. B. (1996). Treponema maltophilum sp. nov., a small oral spirochete isolated from human periodontal lesions. Int $J$ Syst Bacteriol 46, 745-752.

Wyss, C., Choi, B.-K., Schüpbach, P., Guggenheim, B. \& Göbel, U. B. (1997). Treponema amylovorum sp. nov., a saccharolytic spirochete of medium size isolated from an advanced human periodontal lesion. Int J Syst Bacteriol 47, 842-845. 